\title{
Kavram Bilimleri ve Hukuk
}

\author{
Frof. Suheyp Derbil
}

\section{Bhim ve hukali.- - Bilimlerín siniflanmas1,-- Kavram bilingleri.- Kavan redir? - Matenatik.-Flzik.-- Biyoloji.- Ruhbilixni.- Sosyoloji. - Haksuk.}

1. Bilim ve hukuk. - Bilin nedir? Nerede bişar? nertis biter? Birnier arasmda ne gibi ilgier ve baghishar vardy? Bilimis nasıl smflanmaindr? Hukuk bilminin bilknler arasnde yeri re oimahdir? gibi sorumlar üstünde bilghler anlaşmanslardr. Sir lakim bilginler bu sorumlan açikea incelemisler it:

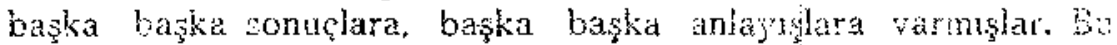
sorumbar izerindeki förusterini açğa vurmams clan bir col

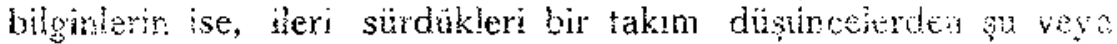
ba antayı şa olduklan sezilmektedir.

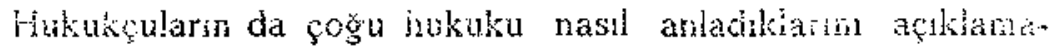
mışlardu. Yazlarmdan huklikn kavrayısłan arasmda bir takmi benzeyissizlihler olduğu sezinlermektedir.

Gerek bilim alanmda, gerekse hukukçuar arasindaki anlasmazikiarn ços̆u hareket noktasınn açlklanmamastudan, belisiz buakınasmdan ileri gelmektedir. Hareket noktas!, bir fikir yapisinn temeli gibidir. Ternelsiz yapl dayaniksı oim. Bogrusu, söze başndan başlamak, kurulacak fikir yapısın temelieinin

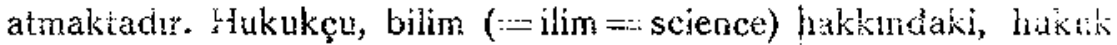
hakkıı̉aki anlayışını açıklamákla söze başlamạııłır.

2. Bilimlerin simflanması. - Bilimin ne olduğunu açsilamak kolay degildir. Bacon'e göre, bilim bir kopyecilik işidi:. Bilgin kendinden ona bir şey katmamalıdır. Eergson a göre "bilimsel araştırma, zihniyle tabiat arasında bir diyalogdur, bir konuşmadr." [1] Bu iki görüş arasında uçurum vardır; uzlaşiımak

[1] Henri Bergson, La pensée et le mouvant, Paris 19.1, S. 290. 
için uzun boyiu ưgraşmaktansa, dar anlamda bilimin ne olduğunu belirterek konuya girmek daha kestirme olur.

Dar anlamda bilim - ki buna arık bilim de diyebiliriz - tarihten veya hayaldan bir veri $(=$ mutta $=$ donnée) alarak bunun gerekli sonuçlarmı araştırır.

Veri, tarihten alınmışsa gözlemi ( $=$ müşahedesi) iyi yaplmıs gerçek bir olay, hayaldan alınmışsa mümkün bir olay olmalıdır. Eğer veri yanlış veya imkânsız olursa utopyaya düşmek işten bile değildir. Bilim ise hakikate ulaşmak amacın güder [2]. Bilimlerin çeşidleri hakkında açık bir fikir edinebilmek için şu cümleleri ele alalım:

1. - İki iki daha dört eder.

2. - Kışın kar yağar.

3. - Doğru oldư̆u anlaşlan bir yargı (= Hüküm = jugement) ile çelişik(=mütenakiz) bir düşünce kabul edilmemelidir.

[2) $H$. Poincaré "Biłmin degeri* başltkl eserine "Hakikati araştırmak etkinliğimizin (=faaliyetimizin) amacı olmalıdrr; insana yaraşan biricik everek (=gaye) budur.» söziyle başlıyor.

Insan yalnız hakikat peşinde mi koşmalıdır? Insanhoğı achların dindirmek

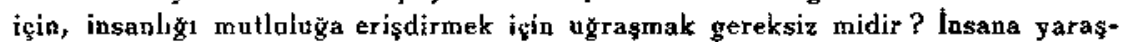
mıyan bir çabalama mıdır? Hị̧ sanmıyorum. Insanlık - iki tavşan arkasııdan ko. şan bir ave1 gibi - bir taraftan hakikati, bir taraftan mutluluğu kovalamıştır ve kovalamaktadır. If̧ yüzüi araırrsa bu ikj amaç arasında çok sıkı bał̆lar vardır.

H. Poincaré, «Hakikat s söziyle yalnız bilimsel hakikatt kastetmemektedir. aHakikat bazen bizi korkutur. Biliyoruz ki o, çok kere hayal kırıcidır ve bize bir ân göründükten sonra durmadan kaçan bir hayalettir» dedikten sonra : ubununla beraber hakikatten korkmamalıdır, çünkü yaloız o güzeldir. Hakikatten söz açırea, şüphesiz önce bilimsel hakjkatten bahșetmek istiyorum; fakat tinsel (= manevi $=$ morale) hakikati de, adalet denilen nesne, görünäşlerinden biri oisn tinsel hakikati de kastediyorum. Kelimeleri kötä kullandı̆̆m, bir birine benzer tarafi almyan iki nesneyi bir kelime altıda topladıgm ve ispatlanan bilimsel hakikatin hiç bir bakımdan duyulan tinse] hakikate yaklaşmıyacă̆ı sanılmasın, ben oniari bir birinden ayırmam, bualardan birini seven ötekini sevmemezlik edemez. Buplardan birine veya ötekine ulaşabilmek için ruhumuzu peşin yarg lardan ve jhtiraslardan (= tutku) kurtarmak, mutlak dogruluğa erişmek gerektir. Bu iki çeşit hakikatin keşfi bizde aya sevinci uyandırır; ber ikiși do gözükǜnce aynı parlakłıkla ışıldar... her ikisı de bizi çeker ve bizdea kaçar; hiç biri durdurulamaz: onlara ulaşdığımızı sandı̆ımız zaman görürüz ki onlar ilerlemektedir ve onları kovalıyan kimse rahat yüzü görmemeğe mahkûmdur.» diyor. (La Valeur de la Science, Paris 1912, S. 1 - i)

Adalet, mutluluk araçlarından biri ve belki de en önemlisi oldư̆una göre, H. Poincaré'nin dïşüncesi törecilere (= moralistes) aykırı görünmemelidir. 
Bunların hepsi birer bilimsel hakikattir. Ancak:

a. - Birinci cümle evrensel ve değişnez bir hakikati ifade ediyor. Bu cümlenin başna (her zaman ve her yerde) kelimelerini ekliyebiliriz: Her zaman ve her yerde iki iki daha dört eder.

b. - Ikinci cümle ile belirtilen hakikatte evrensellik ve değişmezlik yoktur: "Her zaman ve her yerde kıșın kar yağar." demek doğru olmaz. Cünkü her zaman ve her yerde kışın kar yağmaz. Bu cümle olsa olsa bir olay ifade edebilir.

c. - Üçüncù cümle bir ögüt, bir kaide mahjyeti arz ediyor. Insan oğluna ögüt veriyor ve bir. kural belirtivor. Meselâ: «uyun renksiz olduğunu anladiktan sonra renkli de olabileceğini kabul etme! Artık bunu araştırma, boşuna yoruiursıms demek istiyor.

Bu misâllere dayanarak, bilimleri üç büyük kategoriye ayırabiliriz:

1. - Kavram bilimleri (sciences des concepts)

2. - Olay bilimleri (sciences des phénomènes)

3. - Kural bilimleri (sciences des règles)

3. - Kavram bilimleri. Kavram bilimlerini sıralamak için A. Comte'un tuttư̆u yol uygun görünüyor. Comte bilimleri karmaşlkhk derecelerine göre sıralar: en başta en yalin olam, en sonda da en karmaşık olanı gelir [3].

Meselâ: Geometri ile aritmetik arasındaki băğllaşmayı inceleyecek olursak geometrinin sayı bilimi olan aritmetiğe dayandıঢ̆ını görürüz. Geometri ölçer: ölçmek, sayımı ş̧ekil üzerinde uygulamak demektir. Geometride de sayı ve hesap vardir. Ancak, şekil fikri yenidir, sayı bilimine yabancıdır. Bóylece, geometride eski sayı kavramına eklenen bir yeni kavram. şekil kavramı vardır. Bu artan bir karmaşıklıkıı.

Karmaşıklık sırạsına göre kavram bilimlerini altı grupa ayırabiliriz: 1. - Matematik, 2. - Fizik, 3. - Biyoloji, 4. - Ruhbilim, 5. - Sosyoloji, 6. - Hukuk.

[3] Insanların ilk önce basit gerçeklikleri incelediły, ilẹledikce karmaşık gerçekliklerle ilgilenmeğe başlandıơs doğo değildir. Bilákis, insánlar ilk önce en karmaşık gerçekliklerle ilgilenmişlerdir. Ancak, sistemli hir yol tutmak için ya. lından karmaşığa dă̆ru ilerlemek uygun olur. 
Bütün bu bilimlerde bir takım bilimsel kanunlar ortaya atılmaktadır. Bilimsel kanunlar bilimlerin özünü teşkil ediyor. Bundan 'ötürü, kanunun ne olduğunu incelememiz, bu nokta üzerinde anlaşmamız gerekiyor.

4. - Kanun nedir? - Kanun, iki terim (= Had = Terme) arasında şartl t ve zorumlu bir bağllliktır.

a. - *Bir üçgenin açıları eşit ise kenarlarıda eşit olur.»

b. - *Bir katı, bir sıvı içine batırılır ise ağırlığının bir kısminı kaybeder,»

cümleleriyle birer kanun belirtitmiş olur.

Bu cümlelerde şart «ise» kelimesiyle belirtilmiştir; başka kelimelerle de ifade edilebilir. Hatta bazen şart. örtülü de kalabilir: «Eşitkenar üçkenlerin açılar da eşittir., ; ‘Bir sıvı içine batırılan katının ağırlığı azahır» cümlelerinde olduğu gibi. Bu çeşit cümleleri, şartı açıkca gösterecek şekilde tertiplemek her zaman mümkündür. Zorunluluk, kanunu belirten cümlenin başına: ther zaman ve her yerde" veya "nerede olursa olsun" gibi bir söz eklemekle denetlenebilir. Böyle bir ekleme ile de cümledeki yargının dožru olması gerektir. "Nerede olursa olsun, bir üçgenin açılan eşidse kenarlarıda mutlaka eşit olur,», «Her zaman ve her yerde bir sıvı içine batırılan katı ağırhğından kaybeder.» sözlerinde olduğu gibi. Buna «Kanunun evrenselliği» de derler.

Evrenselliği genellikle kanştırmamahdır:

a. - Yer kendi ekseni etrafında yirmi dört saatte bir döner.

b. - Güneş etrafında dönen gezegenlerin (= seyyarelerin) yörüngeleri ( $=$ mahrekleri) eliptiktir, dediğimiz zaman birer genel olay bildirmiş oluruz.

Bu olaylar evrensel değildir. Her zaman bu böyle değildi. Nebüloz devrinde ne güneş vardı, ve ne de yer vardı. Bu çeşid genel olaylara da kkanun" veya "tabiat kanunu* diyenler var. Ancak, bunlarda evrensellik yoktur: birer gerçeklił̧in (= réalité) ifadesi vardir [4].

[4] Tabiat kanunlarında gerçékliçin eksiksiz, kusursuz bir ifadesi bulunduzonu ileri sürmek fazla iyimserlik olur. Ileride gerçekligin daha dogru, daha otraflı bir ifadesi bulunabilecegi süphesizdir. H. Poincaré : «Her hangi bir kanun, eksik ve geçici bir ifadeden başła bir şey deł̆ildir, fakat yerine bir gün üstün bir kanun geçirilmelidir. Şimdiki k̇anun 'balunacak üstūn kanunun kaba bir taslağı halinde kalacaktır." diyor. (La valeur de la acience S. 2`1-252) Bu bakım. dan bildiğiniz tabiat kanubların düzeltilnege muhtą birer tasarı olarak kabul etmek yerinde olur. 
Bilimsel kanunların konuları birer gerçeklik değil, birer imkândır. Geometrinin konusu, gerçek deçil imkândır. Eni boyu ve derinliği olmıan bir nokta, eni ve derinliği olmıan bir çizgi çplak gözle değil, mikroskopla bile görülemez. Fizik veya kimya teoremleri de geometri teoremlerine benzer. Meselâ : «Homojen bir ortalıkta ışınlar doğrusaldır." sözü bir fizik teoremidir. Fakat gerçekde homojen bir ortalık yoktur. Fizikdeki veya kimyadaki su, demir, bakır gibi maddeler-geometrideki nokta veya çizgi gibi - gerçekte bulunmiyan, görülmeyen, elde edilmiyen resnelerdir.

Gerçeklik çok karmaşıktır. Gerçekliği bütün karmaşıkhğ! ile kavrayamadığmı için kavram bilimlerinden yardım umuyoruz.

Anlayışlarımız çok çürük, aklımız çok clìzdır. Bütün çabalamalarmıza răgonen şimdiye kadar «zaman ` ve «uzay» (- mekân -espace) hakkında bile açık bir anlayışa ulaşmış değiliz. Çünkü zaman! ve uzayı ne sinırl olarak, ne de sinirsiz olarak tasarlamak elimizden gelmiyor. Maddenin ve kuvvetin ne olduklarmı da gereği gibi anlamış değiliz.

Montesquieu: "Kanun, eşanın tabiatından çikan zorumlu oranlardır» diyor. Eski idealciler, eşyanın tabiati oldugunu kabul etmiyorlardı, bunu açıkca inkâr ediyorlard.. Eski idealcilere göre maddenin hiçbir özelliği (=hassası = propriéta), hiç bir tabiati yoktu. Descartes'a gelinceye kadar fizikciler maddeyi belirsiz ve belirtilemez bir nesne sayıyorlard. Bir maddenin özelikleri, onlara göre, maddedeki özden (= essence), maddenin bağlı olduğu jadeadan ileri geliyordu. Özler düzenliŏgi gerçekleştiriyordu. «Ylldızlar niçin yerin etrafında daire şeklinde dönüyor? çünkü özlerinde dairesel (= circulaire) hareket ideası vardir. Niçin çam, önceden yapılmış bir plâna uyar gibi, gelişiyor? Çünkü onda özdeksel olmıan (=immateriel) çam özü var. Maddenin vasfı yoktur, madde özlerin gerçekleşmesine yarar. Yalnız başına maddenin hiç bir manâsı yoktur.» diyorlardı.

Bu idealcilið̧in kaynaklarından biri de, gerçekte tam bir düzenlik görülememesinden ileri geliyordu. Gerçẹkde daima düzensizlikler ve noksanlar vardir.

Eflâtunun felsefesinde bu gözlemin ne büyük yeri olduğunu biliyoruz. Tamamen kare veya tamamen yuvarlak madde yoktur; yer yüzünde tamamen doğrusal (- rectiligne) veya tamamen 
dayiresel hareket yoktur. Hâlbuki gerçek düzenlikdir, varhk düzenliktir. Eł̧̆er gördüğ̈ümüz dünyada düzenlik eksik ise bu hâl, varlı̆̆ın zıddı olan bir nesneden mukavemet görmesinden ileri gelmektedir. Varlığın zıddı olan nesne maddedir. Hakikî varlık yalnız özlerdir.

Modern bilim, eski «öz» düşüncesi yerine «tabiat kanunu» sözünü kullanmıştır. ¿Tabiat kanunları adiyle ileri sürülen kaideleri birer bilimsel kanun olarak kabul etmeyenler de var. "Tabiat kanunları adinı verdiy̌miz genel olaylara starihsel kanunlar demek daha dogru olur.

Aritmetik'de zaman ve uzay ayırdları yapılmaz. Geometride yalnız uzay kavram vardır. Insanların ilk önce uzay hakkında bulank bir anlayıșa ulaşdıklari, ardı sıra zaman denilen nesnenin farkına vardıklan kabul edilmektedir. Bergson'a göre, insanlar-hiç bir birine benzemediø̣̆i, benzer tarafı olmadhğı hâlde - zaman uzaya benzetmişierdir. „Uzun zamandan beri..,», «kisa bir zaman. das gibi sözler bunu göstermektedir. Uzun, kısa. gibi sıfatlar ancak uzay hakkında varid olabilir. Zamanda uzuniuk, kısalık olamaz. Kabul edilen zamıan birimine göre olsa olsa çokluk, azhk varid olabilir [5].

Hareket konusunu da içine alan bilimlerde zaman kavramı da vardur. Mekanikte olduğ gribi.

5. Matematik. - Kavram bilimlerinin en basitidir. Aritmetik'de zaman ve uzay kavramian olmadığı gibi, madde ve ruh kavramlan da yoktur. Geometri'de yalinz uzay kavram!, mekanik'de uzay ve zaman kavramiar vardır. Fizik bilimier maddeyi, ruh bilim ruhu tanır. Matematik ne maddeyi, ne de ruhu tanir.

Sayı, bir birimler toplamıdrr. Birim somut (=müşahhas = concret) bir madde değildir; ancak somut bir maddenin bir vasfidur ki biz onu soyutlama (=-'tecrid =abstraction) yaparak madeden ayıryyoruz. Sayı da soyuttur. Bir adamm iki gözü, iki kulağı, iki kolu, iki eli, iki ayağı, iki omuzu ve ilâh.. vardır. Bu benzeyişsiz varlkkların benzer tarafı iki olmasından ibarettir. Her bir göz, her bir kulak ve ilâh.. öteki gözden, kulaktan ayrıdır; ayırdedilebilir. Bunlar birer birimdir. Fakat göz göze benzer, kulak kulağa benzer. Bunlar birer toplam olabilir. Bütün bu toplamların müşterek vasfı iki olmalarından ibarettîr.

[5] Türkçede «çok zamendan beri.", aaz zamanda» denildiğine göre dilimi-

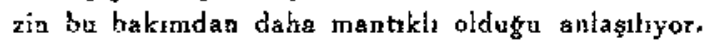


Iki bir sayıdır. Ayn zamanda bir değerdir ( k kymet = valeur). Her sayı bir değerdir. Fakat her değerin tek bir sayıdan ibaret olması gerekmez. Şöyle bir denklemde:

$$
4+2=6
$$

üç sayı vardır. Fakat tek bir değer vardır. $O$ da 6 dır. Değer veya büyüklük, aritmetik işaretlere göre gerekli eylenler yapidıktan somra elde edilen sayıdır.

$$
7-3+9-5=8
$$

denkleminde beş sayı, fakat tek bir degerer vardır. O da 8 dir. Bir denklemin bir tarafından bir birim ȩıkarıtsak eşitlik bozulur, eşitsizlik olur. Yukarıki denklemin birinci saytsından bir birim çıarırsak şöyle olur:

$$
6-3+9-5<8
$$

Sayı, değer, eşitlik, eşitsizlik aritmetiğin dayandiơ̆ı belli başı kavramlardandır. Eşitlik özdeşlik (= ayniyet =identité) demek değildir.

Matematikte hayalin: rolü büyüktür. Ancak hayâl, zekâ ve mantıktan yardm görmelidir. Her savmm ayn bir adı olmahdur. Böylece her says başkalarında kolayca ayırdedilir. Geri kalınış insan topluluklarında pek az sayını adı konmuştur. Bir, iki, üç, dört ve belki de beşten sonra "çok» manâsina gelen bir kelime ile işin içinden çlkmışlardır. Böyle çevrelerde matematik aramamalıdır. Medeni milletler daha ileri giderek sayuları smflamışlardır. Onlar, yüzler, binler ve ilâh... gibi. Bu ondalık smiflamadır.

Ondalık sınfflama sayesinde on rakaml bütün sayılar yaz-mak yolu bulunmuştur. Bu rakamlardan biri suf̣ı dır. Sifır dâhice bir buluş olmuştur. "Eğger eski çağda sıfır bulunnuş olsaydı orta çă̆ olmıacaktı., diye düşünenler vardir.

Matematik, aritmologi (arithmologie) ve geometri kollarna ayrür. Aritmologi üç kola ayrimaktadır: Aritmetik, cebir ve infinitezimal hesap. Bunlara tümler kuram (théorie des ensembles) adı verilen yeni bir kol eklenmiş bulunmaktadır. Tümler kuramı aritmetiğin birinci bölümü olmağa aday sayılabilir. Tümler kuramı genel olarak sayı kavramiyle deǧer, eșitlik ve özdeşlik kavramlarına dayanır. Bir takım bilginler tümler kuramında ne sayı, ne de eşitlik kavramları bulunmadığın ileri sürüyorlarsa da bu doğru deợildir. Bu kavramlar tümler kuramıda başka 
adlar alırlar. Eşitliğe benzerlik veya uygunluk (correspondance), sayıya zenginlik denir. Tümler kuramınn bir kaç teoremine göz gezdirelim:

Bir tüm ayrıştırildıktan sonra yeniden toplanırsa yeni tüm eskisine benzer.

Eğer iki tüm bir üçüncï tüme benziyorlarsa bir birjerine de benzerler.

Eğer bir tüm ikinci bir tümden zenginse ve ikinci tüm de üçüncü bir tümden zengin olursa birinci tüm üçüncü tümden zengin olur.

Bu teoremlerde birim, sayım, değer, eşidlik ve eşidsizlik kavramları bulundư̆u gözälüyor.

Auguste Comte aritmetiği değerler hesabı diye tanmlıyor. Cebiri de eşitlikler hesabı sayabiliriz.

Infinitezimal hesapta cebir teoremlerinden ayr kuramlar vardır ki bunlara infinitezimal çözümleme derler. Bu çözümlemeye göre sonlu (= fini) değerler, yani birimler sonsuz sayıda ve sonsuz küçüklükde parçalara ayrilırlar .Eski Yunanhlar, iğrilerin sonsuz sayıda sonsuz küçüklükde doğrulardan bileşik olduğunu düşünmüsslerdi. Yeni çă̛da bu fikir, geometrik hareket noktasından ileriletilerek soyut sayılanı analizine geçilmiştir.

Aritmoloji'de kurallar yani mantik büyük bir yer tutar. Geometri bambaşkadır. Büyük bir benzeyişsizlik göze çarpar. Geometri'de kurallar büsbütün ortadan kalkmıştır. Geometri tanımlamalarla ve aksiyonlarla işe başiar ve hemen hemen hiç bir kural, yâni hiç bir mantık ögüdü ileri sürmez. Hâlbuki geometri mantığa yabancı değildir. Zaten hiç bir bilim mantığa yabancı olamaz.

Geometride tartışmasi yapılmıyan, hatta sözü bile edilmiyen bir mantık problemi vardır $\mathrm{ki}$ o da tümdengelim metodunun uy* gun ve yerinde olduğu düşüncesidir. Geometri tümevarım yoliyle başlamıştır. Eskiden bir çok uluslar tümevarım yoliyle uzuntukları ölçmekte ve geometri teoremlerini belirtmekte başarı göstermişlerdir. Eski yunanlıların büyük meziyetleri tümdengelim yoliyle sistemli bir geometri kurmuş olmalarında belirmektedir. Bugün geometride tümdengelim metodu genel olarak kabul edilmiştir. Tümen varım metodu uygulanmamaktadır. 
Geometride yeni çağ, çözümlemeyi sentezden üstün tutmaktadrr. Euclid geometrisi ad verilen Yunan geometrisi ise sentetikti. Bu modern geometride düz çizgi, lơri çizgi cinsinin bir çeşididir, doğru yüzey, iğri yüzey cinsinin bir çeşididir ve nihayet $\ddot{u}_{\zeta}$ boyutlu uzay, en boyutlu uzay cinsinin bir çeşididir.

Ölçü, zekânin dahiyane bir icadıdr. Uzay (discontinu) degildir. Bize sürekli (continu) görünür. Çizgive ve dolayısiyle şekillere sayı fikrini uygulamak için yani ölçmek için, zekâ bir takım uylaşml (= conventionnel) birimler yaratmışin. Kulaç, adım, parmak, arşı, metre ve saire.. gibi. Bu ölçülerin thị biri tabiî ve uesnel $(=$ objectif $)$ değildir. Hepsi yapma ve koyfítir. Yapmalik yainz ölçünün büyüklü̆ünde veya ağılh gnnda değil, ne olursa olsun ölçünün gerçeğe aykırı düşmesinde vardır. Elimde bir birinden ayu beş parmak vardır, fakat beş metre ununiusunda bir çizģide bir birinden ayrı birer metrelik beş parça yoktur. Bu bir vylaşı (convention) dur.

Kesir fikri ilk önce geometride doğmuş olsa gerektir.

Bir parmak bölünürse parmak kalmaz; fakat bir cizci bölününce iki çizgi olur. Kesîr fikrinin matematikte uygulatimas! çok sonra olmuşiur.

Şekiller, noktalar, çizgiler, yüzeyler, hacımlar birer bilinsel yapntı ( $\cdots$ fiction) dır. Matematik baştan aşağı şirdir, liemde gatçek şiirdir. Matematikciye de, şair gibi, hayâl lầımdir.

6. Fizik - Kimya. -- Matematikteki kavramlar fizik biiimlerde de göze çarpar. Fizikde de sayilur, denklemier yapul, şekiller, hacimlar hesaba kathlı. Bütün matematilk fizik bilimlere girer. Fizik matematikden daha karmaşiktr. Auguste Comte'un ve A. M. Ampèrin haklan vardır. Fiziğe giren yeni kavramlar nelerdir? Şimdilik "madde ve kuvvets diyelim.

Madde nedir? kuvvet nedir? Ilk önce bunlan betirtmek gerektir. Madde ve kuvvet bizde duyum (=ihsas tyandiran nesnelerdir. Gerçekte aydınlık veya karanlık, soğuk veya sıcak, gürültï veya sessizlik, sertlik veya yumuşaklik, acılik ve tathlık, ağıhlk veya hafifilik duyarı. Bu vasıflardaki farklar fizik bilimlerin yeni kavramlarını ve konusunu meydana getirirler. Eski çağ fizikcilerinin bu anlayışı şimdiye kadar büyük bir değişiklige uğramamıştır. 
Fizik kitaplarında bölümler duyumlarımızın çeşidine göre tertiplenmiştir. Bir bölüm 1sı'ya; bir bölüm optik'e, bir bölüm akustik'e ve ilâh.... ayrılmıştır.

Ancak, bütün bunlar bilimin çocakluk çă̆ıdır, olgunluğu değildir. Fizik biliminin şimdiki tarzda bölümlenmesi fizik düzenliğine göre deł̆il, ruhsal düzenlił̧e göredir. Duyumlar ruhsal olaylardir. Fiziğin konusu duyumlar değil - bu ruhbilimin konusuna girer - duyumların dı̧ sebepleridir. Çevremizdeki fizik olaylardan biri üzerimize birden çok duyum uyandırabilir. Meselâ : ocakta ateş yakınca hem sıcaklık, hem de aydınlık duyarız. $\mathrm{Bu}$ iki ruhsal duyumun tek bir fizik sebebi vardır. Fizik duyumlarımızı deł̆il fizik olayın kendisini incelemelidir.

Matematik kavramlanna fizik bilimi kütle ve cisim kavramlarını eklemiştir. Cisimler, geometrik şekiller gibi birer uzam (=étendu = vüs'at, · intidat) - değildir, cisimler uzamda bir yer tutarlar, yani bir cismin bulundư̆u yerde aynı zamanda başka bir cisim bulunamaz. Buna cisimlerin girilememezliği (=impénétrabilité $\Rightarrow$ derler. $O$ hâlde madde ve kuvveti, ruhbilime dayanmadan, şöyle tanımlayabiliriz:

1. - Madde üç boyutlu uzayda uzamlı bir nesnedir, girilememeżliği vardır. Hareketlidir, fakat kendiliğinden harekete geçmez. Maddeler cisimleri meydana getirirler. Cisimlerin bir birleri - üzerine etkileri vardır. Bir cismin harekete karşı direnç (= mukavemet) niceliờine (=quantité) kütle denir.

2, - Kuvvet hareket doğuran veya hareketi değiștiren nesnedir. Böylece kuvvet hareketin 'kendisi olabileceðo gibi kütle de olabilir.

3. - Fizik olaylar cisimlerin üç boyutlu uzayda hareketlerinden ve değişmelerinden ibarettir.

Fizik bilimlerin konusunu böylece sunırlayabiliriz. Modern fizikte incelenen hareketler dört türlüdür:

1. - Cisimlerin hareketi ki çıplak gözle görülebilir ve her gün görmekteyiz.

2. - Çok daha küçük varlıkların, moleküllerin hareketleri. Bu hareketleri gözle göremeyiz. Bir santimetre küp gazde yirmi milyon milyar molekül varmış. Bu moleküller baș döndürücü bir hızla hareket ederlermiş: saniyede bir kaç kilometre katederlermis. 
3. - Atomların hareketleri. Bir molekül bir çok atomlardan bileşiktir. Atomlar da hareketlidir: girerler, çıkarlar. Bundan da kimya değişmeleri baş gösterir. Atomlar moleküllerin içinde de hareket ederler. Atomların molekül içindeki hareketlerine modern fizikçiler sıkı bir ilgi göstermişlerdir. Molekül üç boyutlu olduğu için atomların molekül içindeki hareketleri pek çok çeşitler göstermektedir.

4. - Elektronların hareketi. Atomların da basit olmadığı anlaşılmış̧ır. Atomlar da bileşiktir: elektronlara ve iyonlara ayrilmaktadır. Negatif elektrik yüklü ise elektron, pozitif elektrik yüklü ise jyon adını ahyorlar. Elektronlar bir iyon etrafında dönmektedirier, yerin güneş etrafında dönmesi gibi. Bir takim şartlar altında elektron atomlar dışan çikar, atom ayrışır $(=$ tahallül eder). Elektronların atom içinde ve atomlar arasındaki hareketierine elektron hareketleri deniliyor.

Bütün bu hareketler, hız bakımından, doğrultu bakımından bir çok çeşidlere ayrılır. Hızın artması, azalması veya değişmezliŏi, düz çizgi, kırık çizgi veya eğri çizgi doğrultularnnda olması, veyahut bir eksen etrafnda dönme şeklinde bulunması, ileri geri gidip gelme şeklini alması mümkündür.

$\mathrm{Bu}$ hareketleri başı başına incelemekle yetinmemelidir. Hareketlerin birbirleri üzerideki etkileri de incelenmelidir. Cisimler, molekïller, ałomlar, elektronlar birbirleririe dokunuriar, çarparlar ve küłlelikleri dolayısiyle bu yüzden hareketleri değişir, hızları artar veya eksilir, doğrultuların değiştirirler, hatta şekillerini değiştirirler. Bu hareketlerin önemli bir çeşidi de titreşim (=ihtizaz =- vibration) dur. Bu hareketler ses dalgaları, ışı dalgaları, isı dalgaları halinde devam eder.

Akar sulardan ne yaptrğımızı göz önüne getirirsek hareketlerin nasıl değiştikleri, deð̧işebilecekleri hakkında bir fikir edinebiliriz. Suyun öteleme $(=$ intikal $=$ translation $)$ hareketi türbinde dönel ( $=$ devranî $=$ rotatoire) harekete, bu hareket de kablolar'da elektrik hareketine dönüşüyor. Elektrik hareketi ise, isteğimize göre, lâmbalarda ışık dalgalarına, sobalarda isı dalgalarına, makinelerde hareket kuvvetine çevriliyor.

Fizikde bir hareket mutlaka başka bir harekete çevrilmez, bazen hareketsizliğe de dönüşebilir; bu hareketsizlikten ileride yeni bir hareket doğabilir. Böylece edimsel bir kuvvet yok edilmiş değil, potansiyel bir kuvvete çevrilmiş olur. 
Bir yayı germek için hareket, kuvvet sarfetmek lâzımdır. Bu hareket, bu kuvvet gerilmiş yayda ne oluyor? Hiç bir hareket görülmüyor. Sarfedilmiş kuvvet, potansiyel kuvvete çevrilmiştir, hareketsizdir. Fakat gerilen ip burakılınca potansiyel kuvvet yeniden edimli olur, hareketsizlikten hareket doğar.

Fizik kanunları iki çeşide ayrılabilir :

1. - Edimli kuvvetlerin edimli başka kuvvetlere çevrilişi kanunlan ;

2. - Edimli kuvvetlerin gizli (potansiyel) kuvvetlere dönüş. mesi veya gizli kuvvetlerin edimli kuvvetlere çevrilmesi kanunları.

Yirminci asir başlarında bütün bilginler tarafından kabul edilen bu ikinci çeşid kanunlar, atom hareketlerinin ve radyoaktivitenin keşfinden sonra gözden düşmüştür. Artık edimli bir hareketten gizli bir harekete geçildiği veya gizli bir hareketin edimli (=- actuiel) bir harekete dönüştüğü kabul edilmemektir. Gerilmiş yayda ve ipde cisim hareketi atom hareketine dönmüştür, atomlar baş döndürücü bir hızla ve şiddetle hareket etmektedir. Ip bırakılnca atom hareketleri yeniden cisim hareketlerine çevrilmektedir.

Geçen asırda kimya, moleküller arasındaki atom hareketlerinin kanunların araştıran bir bilimden ibaretti. Atomların molekül içindeki hareketleri bilinmiyordu. Molekülün üç boyutlu olduğu ve molekül içinde atomun yer deł̆iștirmekle maddenin de vasıflarını değiştirebilecę̆i anlaşıldı. Meselâ: hepsi de 9 atom karbon, 10 atom hidrojen va 3 atom oksijenden bileşik olmak üzere birbirinden farklı 164 çeşid cisim bulundựu anlaşıldı. Bu cisimlerin hepsinin kimya formülü aynen : $\mathrm{C}^{9} \mathrm{H}^{\mathrm{tv}} \mathrm{O}^{3}$ imiş.

Bütün bu farklaşmalar yalnız atomların molekül içinde yer dex̧iştirmelerinden mi ileri şeliyot? Hayır. Atomların basit birer cisim olmadığını da unutmamak gerekiyor. Atomlar da sürekli birer gerçek sayılmaktan çıkmıştır.

Fizik, eski simyagerlerin hülyalarını gerçekleştirmek yolundadır: Radyum helyuma dönüşüyor, uranium radyum oluyor, bakır litium'a çevriliyor. Faraday 1818 de şu yazısı ile bunu müjdelemişti : "Madenleri ayrıştırmak, yeniden bileşdirmek ve saçma sayılan eski deł̧işim (=transmutation) fikrini gerçekleş‘irmek... işte kimyagerin artık çözünlemesi gereken problemler.» 
Faraday'tin vaktiyle kimya dediği nesneye biz șinndi sadece §izik diyip geçiyoruz.

Fizik bahsini kapayabilmek için iki fizik ilkesini ( umde-"= prensip) belimeliyiz:

1. --- Enerjinin sabitliği ilkesi. Enerjinin şekli değișir, dönüşür, enerjiller bir birleri üzerine etki yapar. Fakat bütüin bu değișnelerće değişmiyen bir nesne vardır : o da ènerjinin niceliğidir. Nicelik ( $=$ quantite $=$ kemiyet) ayn kahr.

2. -- Enerjinin dağglması ilkesi. Enerjinin niceily değismez, fakat erki (=: pouvoir=iktidarn) azalı. Enerji toplammn bir kısm etkiltiğini (= müessiriyeti =efficacité) kaybeder, faydasılaşır. is üretmè için şiddst farkı oiması şarttır. Şiddet farkjerı ise azalmakia ve silinmektedir. Tabiat homojenliğe doğru yönelmiģtir, homojensizlik hareketsizlik, uyku ve ölümdirr.

7. Bìyoloji. - Canl cisimleri inceler. Canlı cisimlerde äreme ( - tanasül =- reproduction) biricik üretim (= istihsâl = = production) yoluciar. Canhlarm da, fizik cisimler gibi, bir takam kanuniara

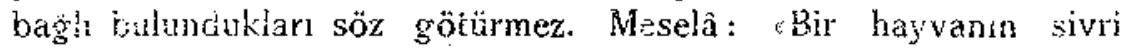
disleri varsa et sindirmeğe elverişli kursa ga da vardur." diyebiliriz.

Biyolojide, fizik alannda görülmeyen bir takım olaylar göz: çarpmaktadır. Besleniş (=nutrition = tagaddi) bu arada ileri sî. rebilir. Organizma özümler (=temsil eder :-=assimile) ve yadımla: (= muzadi temsil $=$ desassimile). Bir takın yeni maddeleri içine alır ve bir takım eski maddeleri dışân ç̧kartr. Bu sürę̧ ( $\because$ vetire = processus) az çok düzgün evreler gösterir: baş̧iang̊çla özümleme üstündür, organizma büyür, sonralan özümletne ve yadimianua hareketleri denkleşir, daha sonra yadmiama üstain oìur, ve organizma ölmeden önce çökmeğe başlar.

Canì variklarda organlar ve dokular ( $\because=$ nesicler $:=$ tissus) is birligi ederier. Organizmanm çeşitli kısımları sanki kamui (= müşterek := commun) bir irade taşrllar.

Organizma ortaya uyar. Organlar temrinle gelişir. hnorganilk cisimler veya yâptı̆̆ımı âletler böyle değildir. Değirmen taş̧ veya biçak kuilandıkça aşınır. Bir adeJenin (= Kas =muscle) bir kerniğin, bir sinirin ișletilmesi, gelişmesini, büyümesini, kuvvetlenmesini săğler.

Olüm, hayat ilkesinin gitmesi, inorganik kuvvetlerin kurtulmasıdır. Ölümle herşey değişir. Artık ne besleniş, ne savunme, 
ne iş birliği, ne düzenlik, ne de üreme vardir. Çürüme ve ayrışma beşlar. Artık madde fizik kanunlarmın etkisi altına girmiş. tir. Hayat, ayrı bir ilkeye bağlı özel kanunlara göre hareket eden bir varliktır.

Kanunlar, yalnız başlanna hiçbir alanda, hiç bir olayı açıklamağa yetişmezler. Kanunlann yanı başında yapilar vardır. İ̧inde yaşadığımız güneş ilkesinin bir yapısı vardır, güneşi doğuran nebülözün de bir yapısı vardı. Gökten düşen kar tanesinin bir yapısi vardır, kar tanesini doğuran bulutun da bir yâpisı vardı. Çam ağacının bir yapısı vardır, çam ağacını dơ̆uran çam çekirdeğinin de bir yapisi vardı.

Organik yapılar, inorganik yapılardan çok farklıdır. Bundan dolayı, aynı kanunun etkisi altinda bulunsalar bile, organik cisimlerle inorganik cisimler başka başka olaylar gösterirler. Lâboratuvar denilen suni yaplarda bilginler öyle olaylar meydana getiriyoriar ki tabiatte bu olaylara hiç rastlanamaz. Canl cisimler en iyi donatılmış birer laboratuvardur: yapıları inorganik alanun tanımadıł̆ olayları meydana getirmeğe elverişlidir.

Organik yaplar nasil meydana geliyor, nasil meydana gelmiştir? Bunu bilmiyoruz. Bir takım varsayımlar, bir takım kuramlar var... fakat hiç biri bir bilimsel pekinlik $(=$ certitude scientifique) degíldir.

İlk ağaçların yer yüzünde nasıl belirdiklerine akıl erdiremiyoruz. Fakat bir çekirdekten ał̧acın nasıl çıktığına aklımız eriyor. Çekirdekte aŭacın daliarın, yapraklarını sanki görüyor gi. biyiz. Belki de yer güneşin ışı̆ı ve sıcaklığı ile döllenerek seyrine doyamadiğınız biteyleri ( $=$ flore) doğuran ana oimuştur. Bitkilerin üstünde hayvanlar gelir. Descartes, insan olmıyan hayvanlarda ruh [6] olmadı̧̆ın ispatlamă̆a çalışış. Fakat bir çok hayvanların bir takım davranışlarında insan davranışlarına okadar benzerlik vardır ki bütün hayvanları içgüdü ile hareket eden bìrer otomat sayabilmemize engel oluyor. Hayvanlar da haz veya acı, istek veya korku duydukların gösteriyorlar. Haz ve acı ile maddî dünyadan ayrı büsbütün yeni bir dünyaya, ruh dünyasına girmiş oluyoruz.

[6] Gerçekde ruh var midır? Hattâ insanlarda rah var midur? Bunu ispat. lamak kolay olmasa gerektir. ļ̧görü ile bir takın olayların varlığın duyuyoruz: Acı, sevinç, kayğ gibi.. Bunlara ruhsal olaylar diyoruz Ancak bu olayları varliłr rah adı verilen bir nesnenin varijğınt ispatlamaz. Başka bir ad verseydik ne olacaktı? Áncak bu konunun tartı̧̧ması kendimize çizdiłgimiz çevçevenin dışında katır. 
Ruhun vücut üstündeki etkileri apaçık deçilmi? Sevinç sağIığımız korur, geliştirir, acı sağhl̆̆ımızı alt üst eder. Heyecanlar bir takım hareketlerle belirir, düşüncelerimizi sözle açığa vururuz. Bunlari bilmeyen kim vardır?

Ancak bu hâller biyolojinin konusunu karmaşıkłaş̧ırmaktadir. Eğer hayvanın bir birinden ayri iki hayatı varsa ve eğer ruhsal hayat üzerinde etkiler yapyorsa biyolojinin konusu birden dörde çımış olur. Biyoloji artık yalnız maddî hayałı değil, ruhsal hayatı da, hattâ ruhsal hayatın maddî hayat üzerindeki etkilerini ve tam tersi, maddî hayatın ruhsal hayat üzerindeki etkilerini de incelemek zorunda kalıyor demektir. Biyo-psikoloji bilimi bu ihtiyaçtan doğmuş bulunuyor.

Vücut hareketlerini, sinir hareketlerini atom veya molekül hareketlerine benzetebiliriz. Buna akhımı yatar. Fakat ruhsal olaylari, hazları, acıları, sevinçleri, kokuları ve düşünceleri de atom hareketleriyle açiklamałăa kalkışmak saçma olur.

Bugüne kadar insanliğin elde ettiği bilgiler okadar az ki, ruhsal olayları deł̧il, beynimizde geçen olaylarr bile anlamaktan uzak bulunuyoruz. Doğrusu aranırsa, bütün bilimlerin hareket noktaları esrar perdeleriyle örtülü kalır.

8. Ruhbilim: - Eskiden bu bilim bizde :Ruhiyat", "Psikolocya", "Psikoloji " adlanı takılmıştı. "Çocuk ruhiyatt". Halk psikolocyası, veya Kadın psikolojisi gibi sözler kullanilırd. Bu konular üzerinde incelemeler yapanlar, eserler. yayinhlyanlar olmuştur. Bütün bunlar kavram bilimlerinin dışında kalır. Olsa olsa olay bilimleri arasında yer alabilir. Kavram bilimieri evrensel kanunları belirtir, belirtmeğe çalışır. Evrensel-kanunlar olaylarm incelenmesiyle bulunur. Evrensel kanunların değeri olaylara uygunluk derecesiyle ölçülür. Ancak olaylarnn incelenmesi, kavram biimleri için bir temeldir, yapı değildir. Kavram bilimleri ayakta durabilmek için böyle sağlam birer temele dayanmalıdır; yoksa kolay yikllur.

Kavram bilimi olarak ruhbilimde ruhsal ( $\approx$ psychique) hayaton bağh bulunduğu kanunlar araştırılır.

Bir duyguyu, bir düşünceyi veya bir isteği bir molekül veya bit atom hareketi olarak kabul edemeğimiz için ruhbilimi, fizik bilimlerden ayird etmek zorunda bulunuyoruz. : 
Ruhbilimin konusu olan dünya. değer ( $=$ valeur) dünyasıdır. Maddî dünyanın kendinden deģeri yoktur. Maddí varlıkların ve fizik olayların - bir takımı insanlar tarafından iyi, bir takım da kötũ sayılabilir, bir takımı insanlar üzerinde haz; bir takımı da acı duyurabilir.

Bu hâl, bir takım maddî varlıkların ve fizik olaylanın kendiliğinden iyi olduğunu göstermez, insanlar üzerinde iyi duygular uyandıran birer araç olduğunu anlatır. Düzenlił̧in, bollư̆un, güzelliø̆in dełgeri, bunları gören, anlıyan, bunlardan haz duyan, sevinç duyan insanlar dolayısiyledir. Kıtlık, kargaşalık veya çirkinlik insanlar üzerinde acı duygular ve düşünceler dołmasına sebep oldư̛̆ için kötü șayilır. Haz, hakikat veya eyi niyet gibi nesneler ise kendiliğinden birer değer if̣ade ederler. Böylece ruhsallik alanına girmiş oluyoruz.

Nasil fizik dünyasında ank olarak bakır, demir veya gümüş yoksa hattâ sun'î olarak ta elde edilememiş bulunuyorsa ruhsallık dünyasında da arık olarak duygu, zekâ veya iradenin varlıð̆ı ileri sürülemeż. Gerçekte bunlar da az çok kanşıkhk olsa gerektir. Tasavvurla (= tasarım - représentation) hiç bir ilgisi olmiyan bir haz veya bir acı var mıdır? Duygu ile hiç bir ilgisi olmiyan, hiç bir haz veya hiç bir acl duygusuna bağlı bulunmiyan bir düşünce var mıdır? Duygudan büsbütün arık düşünce, düşünceden büsbütün ark duygu gerçekte yoktur. Bir takım yapuntılarla (= fiction) gerçek olmiyan, bir dereceye kadar şematik bir dünya yaratıyoruz ve bu dünyayı - bu bilimler ve soyutlamalar dünyasını - okadar kuvvetle tasarhyoruz ki üzerimizde gerçek dünya kadar etki uyandrriyor.

Akıl hakikati yanlıștan ayırmak ister. Akıl soyutlamak (=tecrid etmek) ister. Akıl bireyselde ( $=$ ferdî) ve özelde geneli ve evrenseli arar. Fakat yanlışlı̆ga düşer, soyut kavramları tasarlıyamaz, geneli ve evrenseli de kavrıyamaz, Çırpınır, durur.

Duygular, düşüncelerle boy ölçüşür. Bazen üstün gelir; düşünceleri ezer. Bazen akıl üstün gelir, duyguları ezer ve söndürür. Düşünceler ile duyguların denkleşme halinde bulunduğu da olur. Duygular da çok çeşitlidir. Güzel bir sanat eseri karşısında duyduğumuz haz ile serin bir rüzgâr karşısında duydư̛̆muz haz bir birine benzemez. Ayă̆ımız burkulunca duyduğumuz acs, gönlümüzü kıran bir hareket karşısında duyduł̆umuz, acıdan çok farkhdır. 
Bir takım duygular ve düşünceler geçmiş ile iłgili olabilirse de irade yalnız gelecekle ilgili olabilir. Irade, bir amaç seçerek ona ulaştıracak araçları bulmak ve düzenlemek isteği ve çabalaması diye açıklanabilir. Irade üzerinde geçmişdeki görgü ve bilgilerin etkisi büyüktür. Geçmişte bizde haz uyandırmış nesnelere benzeyen şeyleri elde etmek, bizde acı uyandırmıs nesnelere benzeyen şeylerden sakınmak isteriz. İstekler ile tiksintiler ( $=$ aversions) arasında da hazlar ve acilar arasında oldư̆u gibi bir çok farklar vardır. Írade işlerine de akıl karışır. Sürekli hazları, geçici hazlardan, ortaklaşa hazlanı, bireysel hazlardan üstün tutar ve hakikate üstün bir değer verir. İrade amacı seçer ve akıldan bu amaca ulaştıracak amaclan bulmasin ve düzenlemesini ister.

Bütün ruhsal olaylan bir kelime altında toplayabiliriz: bilinç ! Ruhsal olaylar bilinçli olaylardır. Altbilinçli (= subconscient) olaylar da bilinçlidir. Bilinç az veya çok açık, az veya çok şiddetli olabilir. Şiddeti veya açıklı̆ı az olan veya çabuk unutulan bilinçii olaylara altbilinç diyorlar. Hazlarımız, acılarımız, düşüncelerimiz, iradelerimiz ve gevşekliklerimiz birer bilinçli ruhsal olaydır.

Bilinç bütün bilgilerimizin temelidir, kaynağłdır, esas şartıdır. Nasıl gözsüz görülemez ise bilinçsiz bilgi edinilemez. Fakat bilinçi belirłmek çok güçtür. Bilinç bilimin en bliyük sırrıdrr.

Maddì olaylar ile ruhsal olaylar arasındaki fark okadar büyüktür ki bir çok bilginler ve filosoflar bilimleri sımıflama işini bu farka dayandırmışlardır. Bunlara göre iki tựrlü bilim vardır: madde bilimleri, ruh bilimleri.

Ancak ruhbilim hakikatte bir kavram bilimi midir? Hakikî ruhsal kanunlar var midır? Yoksa alan yalnız tarihe yani olay bilimine mi aittir? Ruhbiliminde de teoremler yerlerini tasvirlere (= betimlere) brrakmalıdır?

Fizikte çok önemli ve verimli bir yer tutan enerjinin sabitliği düşüncesinin ruhsallık alanın da kaplıyamiyacağı meydandadır. Zekâ, duygu, irade gibi, ruhsal enerjilerden biri azalınca ötekinin artması gerekmiyor. Meselâ: zekâ clizzlaşınca duygunun veya iradenin kuvvetlenmesi gerekmiyor. Böylece bir kimsenin ruhsal enerjileri toplamı sabit kalmiyor, bilâkis toplamda artmalar veya azalmalar görülüyor. Bu hâl her gün, her saat göze çarpan olaylardandrr.

Duygular, düşünceler, iradeler - fizik enerjileri gibi - verildik- 
ce azalan sabit miktarlar da değildir. Coşkunluğu ile başkalarını coşturan bir kimsenin coşkunluğu azalmaz. Ö̆rrencilerine bir çok bilgiler vermekle bir ögretmenin bilgileri eksilmez.

Ruhbilimin sistemli bir bilim olarak gelişebilmesi fizikten ve biyolojiden çok daha büyük güçlüklere çarpmakta ise de başka bir bakımdan, fizik bilimlerden üstün bir durumda bulunmaktadır. Fizik veya biyolojik olayları, dogrudan doğruya deð̆il bir takım araçların yardımiyle ögrrenebiliyoruz. Ruhsal olayları ise doğrudan doğruya biliyoruz. Benzimizin sarardığını veya yüzümüzün kızardığını ancak aydınlıkta aynaya bakmak suretiyle öğrenebiliriz. (Araçlar : ışık, ayna, göz...) Beynimizin kabardıŏını, kara cił̌erimiziṇ şiştiŏıini, böbreợimizin berelendiợini veya kör bağırsağımızın yaralandığını ö̆grenebilmek için bir takım uzmanların uzun boylu araşturmalar, incelemelér yapmaları da gerekiyor. Bunları kendi kendimize öğrenmek imkânından bile mahrum bulunuyoruz. Hâlbuki sevindiğimizi, üzüldǚ̆ümüzü, ve ilâh... ơ̈̆̆renmemiz için hiç bir araca ihtiyacımız yoktur. Bu sebepledir ki, bu üstün durumu dolayısiyledir ki ruhbilim, ampirik olarak, fizikten ve biyolojiden çok önce gelişmiştir. Ata sözlerinde, destanlarda, masallarda pek çok hakikî ruhbilim vardır. Eski çağlarda filozoflar, bilginler fizikten çok ruhbilim ögrenmişlerdi. Bugün bile en bilgin bir biyolojist, ruhundaki olayları vücudündeki olaylardan çok daha jyi bilir.

Fizik veya biyolojik olayları bir takım araçlarla öğrenmemize karşılık ruhsal olayları araçsız ögrenmemizden doğan üstünlüğe bir ikinci üstünlük daha katılmaktadır. $O$ da şudur: fizik veya biyolojik olaylar birer fenomendir; yani bu olaylar belki de bize göründüzünden başka türlüdür. Uzayda hareketler üzerimizde ışık, ısı, ses intibalarını uyandırıyor. Bizzat hareketler belki de büsbütün başka mahiyette birer olaydrr. Halbuki ruhsal olaylar bizim anladığımızdan başka mahiyette olamaz. Araçsız edindiğimiz ruhsal bịlgiler birer fenomen değildir.

9. - Sosyoloji. - Burada sosyolojiyi bir kavram biiimi olarak ele alıyoruz. Sosyoloji şartlı durumlarm gerekli sonuçlarını belirten, toplulukların bał̆lı bulundukları bilimsel kanunları, evrensel kanuniarı araştıran, bulan, ortaya koyan bir bilim koludur. Sosyoloji ne tarihtir, ne de kural bilimdir.

Bilimsel kanunlar - yukarda açıkladığımız gibi - şartlı bir durumu ele alı, ve bunu reger veya eise edatlarndan biriyle 
ifade eder ve ele aldığı şarth durumun gerekli sonucunu belirtir. Bu gerekli sonucun başına "her zaman ve her yerde" veya "nerede oiursa olsun "gibi bir ibare eklersek yargının yine doğru olması lâzımdır.

Evrensel bir sosyoloji kanunu olarak şunu ileri sürebiliriz: nerede olursa olsun, bir topluluk üyeleri arasında kamul (= müşterek - commun) inançlan kalmazsa bu topluluk dağılmak yolunu tutar.

Sosyoloji kitaplarında böyle bilimsel kanunlardan başka bir çok şeyler vardır. Mesela: Profesör Kessler'in sosyoloji kitabında çok iyi ögütler, çok güzel anlatılmış tarih vakaları, çok parlak düsünceler vardır. Fakat ben bu kitapta bilimsel sosyoloji kanunlarına rasthyamadın. Bu değerli kitabı Ũniversiteli gençlere hararetle tavsiye ederim: kendileri için çok faydal ögütler bulacakiardır. Fakat, bu kitapla sosyoloji öğrenilebilece ơini ummuyorum. Bilâkis, sosyolojinin ne oldươu hakkında yanlış düşüncelere sapılacağından korkarım. Buna karşılık, Profesör Duprat'nın kitabı bilimsel bir sosyolojinin ne olması, nasıl olması gerektiğini bize açikça gösteriyor [7]. A, Comte'un sosyolojisi de karmakarışıtır. Kitabı, kural bilimlerini ilgilendirẹn bir çok düşüncelerle doludur. îleri sürdüğü üç hâl kanunu bile bir bilimsel kanun degildir [8]. Fakat Comte bilimsel bir sosyoloji kanunu sezinleyerek düzenlik ve ilerlemes kuramı şeklinфe ileri sürmüştür. Comte'un bu kuramını şôyle bir kanun kilığına sokabiliriz: Nerede ohursa olsun insan toplulukları içinde düzenliğin kökleşınesi için ilerlemenin olmaması, ilerlemenin gerçekleşmesi için düzenliğin bozulmásı gereklidir. Durkheim ile Pareto bilimsel bir sosyolojinin nasıl olması gerektiğini doğru olarak belirtmişler ve kural bilimlerine sapmaktan, bir takım ögütler. vermekten sakınmasını bilmişler ise de eserlerini, olay bilimlerini ilgilendiren bir çok tarihsel incelemelerle dolmuşlardır. Böyle bilginleri, bilimin yanısıra tarih yaptıkları için kötülemek isternem. Bilimsel bir sosyolojinin kurulması, tamamlanmış de ợildir; buna ulaşmiş de giliz. Ulaşamayınca bilginlerin, olaylan inceliyerek evrensel teoremiere yükselmẹk için çabalamaları̣ hoş görmelidir.

[7] G. L. Duprat, Esquisse d'un traité ne sociologie, Paris, 1936.

[8] İnsan topluluklarının tanrısal, metafizik ve pozitif ołnak üzere ï̧̧ hâłden geçtikleri iddiası, geçnesi gerektiłyi iddiası bilimsel bis kanun deyildir. Bu, olsa olsa tarihsel bir gözlem olabilir. Kendi hesabıma bu gözlemin doğru oiduğuna inaninyorum. 
Ancak, eserlerinde bilime tarih katıştırmağa, hattâ isterlerse buna bir takım ögütler ve ahlâk kuralları eklemeğe hakları olabilirse de bilimle tarihi veya ahlâkı bir birine karıştırmağa ve bilimi bulandırmała hakları olmasa gerektir.

Sosyolojinin başlı başına bir bilim olduğunu ișpatlamak için sosyal (=toplumsal) olayları başka bilimlerin konulanna giren olaylardan ayırdetmek gerektir. Durkheim'e göre sosyal olaylar dış ruhsaldır (= psychique extérieur) bireysel bilinçlerin dişında ruhsal (psychique en dehors des conciences individuelles) olaylardır. Dış ruhsal olaylar: bir devletin kanunları, bir milletin dili, para sistemì, dinî inançları gibi nesnelerdir. Bu nesneler düşünce ve duyguların etkisi altındadır, yani rubsaldır; fakat bireysel bilinçlerin dışındadır. Bu dış ruhsalhk ferdler üzerine etki yapar ve geniş ölçüde ferdlerin düşüncelerini, duyguların ve davranışlarını sınırlar. Böylece sosyolojinin konusunu belirtmek için kullanılan "dış ruhsal olay "veya stoplusal bilinç" ( $=$ conscience sociale) gibi sözlerin manaları açık değildir. Ruhsallık ferdlerin içindedir. FerdJerin dışına çıkınca ruhsallık alanından çıkılıış olur. Bu böyle olunca "dış ruhsalhk" ve toplumsal bilinç" sözIeri manasız ve hattâ çelişik olur. Dış ruhsallık demek rubsal olmıyan ruhsallı demektir. Bu ise saçma bir sözdür (9).

O hâlde toplumsal olay nedir? Bilinçli varikların bir birleri üzerlerine yaptıkları etkiler ve tepkilerdir. Toplumsal olayın ruhsal olaydan farkı birincisinin dışardan göżlemi yapılabilmesi, ikincisinin ancak içebakış (=introspection) ile ferdin kendisi tarafından bilinmesinde ve başkası tarafından gözleminin yapılamamasındadır. Meselâ: sevmek ruhsal, evlenmek toplumsal bir olaydır.

Ruhsal olay dişardan görülmez, toplumsal olay dişardan görülür.

10. Hukuk. - Hukuka kavram bilimleri arasızda bir yer vermek çabalaması yenidir. Profesör Ernest Roguin $1889^{\prime} \mathrm{da}$ yayınladığı "La règle de droit» başıklı eseriyle denemiştị.

Hukukun başli başına bir kaviram bilimi sayılabilmesi için \$̧u iki şartın varlı̆̆ı gereklidir.

1, - Hukukî olayları başka türlü olaylardan ayırdetmeğe yarayacak bir ölçüt (=criteriüm = kısdas) bulunmalıdır.

[9] Claude Beraard : aBilim ciddileştirilmelidir. Çünkü bilim, şok kere halk tarafından farkına varılmadan en büyäk saçmalan söylemek firsatını verir.» diyor. 
2. - Hukukî olayların bağlı bulundukları evrensel kanunlardan bir kaç tanesi olsun belirtilmelidir.

Ilk önce öiçütü arayalım : hukukî olayların çoğu aynı zamanda toplumsaldır. Ilktisadî olaylarn da çoğu toplumsaldır, Problem, yalntz toplumsal olan olayla hukukî olayı ayırdetmektir [10]. Ölçüt şudur: hukukî olmiyan toplumsal olaylar fizik yaptırımlara (=müeyyidelere) dayanmazlar. Hukukî olaylar fizik [11] müeyyedelere dayanırlar. Meselâ : bir sivil adamın rastladı̆̆ı bir tanıdığına selâm vermesi toplumsal bir olaydır. Bir erin rastladı̛̆̆ı bir subaya selâm vermesi hukukî bir olaydır.

Sivil selâm vermezse hiç bir fizik cezaya çarpılamaz. Asker selâm vermezse fizik bir cezaya çarpllabilir.

Demek oluyor ki hukukî olaylar, toplumsal olayların daha karmaş̧k bir çeşididir. Bu karmaşıklık, yani hukukî olayların fazla olarak bir takım fizik müeyyidelere dayanması hali, hukukî olayları olmiyan olaylardan ayırdetmek için yenilebilecek açık bir ölçüt sayılabilir.

Hukukun konusuna giren olaylar bir takım evrensel kanunlara bağlanabilir mi? Böyle kanunlar bulunmus mudur? Hukuku bir kavram bilimi olarak değil de bir olay bilimi olarak, yani tarih gibi incelemek bize kolay geimektedir. Bundan dolayı kavram bilimi olarak hukuk pek az işlenmiştir. Sosyolojiden bile daha az işlenmiş olduğundan ötürü olacak ki Profesör Adrien $\mathrm{Na}$ ville hukuka kavram bilimleri arasında yer vermemiştir [12].

Biz burada bir kavram bilimi olarak hukuku belirtecek degiliz. Yalnız, hukukun kavram bilimleri arasinda da yer alabileceğini ispatlamakla yetineceł̆iz. Bunun için de hukukun bir kaç evrensel kanununu ortaya atacağız. Hakukun böyle evrensel ve bilimsel bir kaç kanunu bulunmuş ise daha başkalarının da bulunabilecełơni kabul etmek kolay olacaktır.

[10] Hukukî olayların gok kere toplumsal olmaları sosyolojiden ayrı bir hukuk biliminin bulunamyacağın ispatlamaz. Biyolojik olaylarn çoğu da fizik olaylardandir. Bu hâl. fizikten ayn bir biyoloji biliminin bulunmasına engel olamaz.

[11] Hapis, sürgün, ölïm cezalar, fizik müeyyedelerdịr. Para cezaları fizik raüeyyede saylimaz: maddî (= özdeksel) bir müeyyededir. Bu bakımdan efizik veya maddî müeyyedelere dayantr." demek daha doğru olur. Bìz sözü kısa tut. mak için yalnız «fizik müeyyedeler dedik. Esasında para cezası ödenmez veya ödenmezse hapis cezagına çevrilerek uygulanır. Bu bakımidan fizik mäeyyedeyi esas olarak ele almak yanlıs olmaz.

[12] Adrien Naville, ctassification des sciences. Paris 1920. 
Işte evrensel hukuk kanunlarından bir kaçı :

1. Her zaman ve her yerde her hakkın bir etkin (= actif), bir de edilgin (= passif) öznesi (= sujet) vardır,

En az bir etkin ve bir edilgin öznesi bulunmiyan hukuk yoktur.

Hukukun bu evrensel kanununu her türlü hukukî durumlara uygulayabiliriz, ve doğru oldư̆unu görürüz.

2. Her zaman ve her yerde hukukun bir oznesi bir de konusu vardır. Hukuk varsa daima ve mutlaka ozne ve konu da vardır. Öznesiz veya konusuz hukuk olmaz.

Mülkiyet hukukunda mülk konu, mülk sahibi öznedir.

3. - Her zaman ve her yerde hukuk ya mutlak veya bağntıh olur.

Mallarım üzerindeki hukukum mutlak, bana borçlu bir kimse üzerindeki hukukum bağıntılıđır. Mallarımı istediğim gibi kullanabilirim, atarım satarı̣m, baọ̆ışlarım ve ilâh.. [13] Bana borçlu olan bir kimseyi istediłgim gibi kullanamam; ondan ancak borcunu ödemesini istiyebilirim.

4. Nerede olursa olsun, etkin öznenin hakları ile edilgin öznenin borçları daima ve mutlaka eşittir.

Benim bir kimseden alacăım 100 lira ise o kimsenin bana borcu 10 J liradır, daha az veya daha çok olamaz.

Kavram bilimi olarak hukukun bir takım evrensel kanunlannı, teoremlerini daha ortaya atabiliriz. Bu kadarı dâvamızı ispatlamağa yetişir.

Óyle sanıyorum ki, hukukun bilimsel kanunların bulup belirtmek sosyolojinin kanunlarım belirtmekten daha kolay olacaktır. Nitekim bu hususta denemeler yapan Profeser. Ernest Roguin [14] ile Profesör E. Piçard [15] büyük ve parlak başarllar göstermişlerdir.

[13] Mutlak bukukların çờu üzerinde bir takım kısıntılar yapılmıştı̣, ve yapilmaktadır. Mallarımtzı istediṛ̌imiz gibi satamiyoruz. En yüksek flatı kamusal idareler (yerine göro Belediyeler veya Hükûmetler) taraftndan tesbit olunur. Bu yüzden bir takım mutlak hukuk, bağıntılt olayor, mutlaklığın kaybediyor.

[4] Ernest Roguin, La Seience Juridique pure, Paris, Lausanne 1923.

[15] Edmond Picard, Le droit pur, Paris 9920. 